\title{
Ketahanan Pangan, Asupan Zat Gizi dan IMT Pada Remaja Pasca Bencana Di Kota Palu
}

\author{
Ummu Aiman*1, Diah Ayu Hartini ${ }^{2}$, Ariani ${ }^{1}$, Nurulfuadi ${ }^{1}$, Aulia Rakhman ${ }^{1}$, \\ St. Ika Fitrasyah ${ }^{1}$, Fendi Pradana ${ }^{1}$, Devi Nadila ${ }^{1}$ \\ ${ }^{1}$ Departement of Nutrition, Faculty of Public Health, Tadulako University, Indonesia \\ ${ }^{2}$ Departement of Nutrition, Palu Health Polytechnic of the Ministry of Health, Indonesia
}

\begin{abstract}
Author's Email Correspondence (*): ummuaimans.ua@gmail.com $(+6285241466733)$
\end{abstract}

\begin{abstract}
ABSTRAK
Bencana memiliki dampak yang dapat merugikan manusia, termasuk remaja yang merupakan masa emas dimana anak harus dibekali makanan yang cukup gizi sebagai acuan dasar untuk kelangsungan hidupnya yang akan datang tanpa mengalami gangguan yang akan mengganggu proses tumbuh kembang. Penelitian ini bertujuan untuk mengetahui ketahanan pangan, asupan zat gizi dan indeks masa tubuh (IMT) pada remaja pasca bencana di Kota Palu. Metode yang digunakan adalah survey deskriptif dan dilaksanakan di Sekolah Menengah Pertama (SMP) Negeri 3 Palu yang dekat dengan lokasi bencana gempa bumi, tsunami dan liquifaksi dengan total sampel 96 responden. Hasil penelitian menunjukkan bahwa remaja dengan kategori tahan pangan lebih besar $(61,46 \%)$ dibandingkan dengan kategori rawan pangan dengan kelaparan $(10,42 \%)$ dan kategori rawan pangan tanpa kelaparan $(28,12 \%)$. Kemudian asupan energi dengan kategori kurang lebih besar (98,96\%) dibandingkan dengan kategori cukup $(1,04 \%)$ dan IMT siswa sebagian besar masuk dalam kategori underweight $(58,33 \%)$. Kesimpulan bahwa remaja yang terkena dampak bencana masih termasuk dalam kategori tahan pangan namun asupan gizi kurang yang mengakibatkan berat badan kurang sehingga berpengaruh pada IMT kategori underweight.
\end{abstract}

Kata Kunci: Remaja; Pasca Bencana; Ketahanan Pangan; Asupan Gizi; IMT

Published by:

Tadulako University

Address:

Jl.Soekarno Hatta KM 9. Kota Palu, Sulawesi Tengah, Indonesia.

Phone: +628114120202

Email: Preventif.fkmuntad@gmail.com
Article history :

Received : 20062021

Received in revised form : 28062021

Accepted : 30122021

Available online 31122021 


\begin{abstract}
Disasters have an impact that can harm humans, including adolescents, which is a golden period in which children must be provided with sufficient nutritional food as a basic reference for their future survival without experiencing disturbances that will disrupt the process of growth and development. This study aims to determine food security, nutrient intake and body mass index (BMI) in postdisaster adolescents in Palu City. The method used is a descriptive survey and carried out in junior high schools (SMP) which are close to the locations of the earthquake, tsunami and liquefaction disasters with a total sample of 96 respondents. The results showed that adolescents in the food insecure category were greater (61.46\%) compared to the food insecurity category with hunger $(10.42 \%)$ and the food insecurity category without hunger (28.12\%). Then the energy intake in the category of less was greater (98.96\%) compared to the moderate category (1.04\%) and the BMI of the students was mostly in the underweight category (58.33\%). The conclusion is that adolescents who are affected by the disaster are still categorized as food resistant but lack of nutrition results in underweight so that it affects BMI in the underweight category.
\end{abstract}

Keywords : Adolescent; Post-Disaster; Food Security; Nutrients Intake; BMI

\title{
PENDAHULUAN
}

Indonesia merupakan salah satu Negara yang berpotensi rawan terhadap bencana, karena keadaan geografisnya seperti gempa bumi, tsunami, tanah longsor, letusan gunung berapi, banjir, angin putting beliung dan kekeringan. Ketika bencana terjadi, secara langsung akan membuat masyarakat tinggal di tempat yang memiliki segala keterbatasan, baik dari segi sandang, pangan maupun papan (1). Kejadian bencana mengalami peningkatan setiap tahun. Pada tahun 2012 terdapat 1.811 kejadian dan terus meningkat hingga pada tahun 2016 terdapat 1.986 kemudian Gempa yang mengguncang Kota Palu pada tanggal 28 September 2018 merusak ribuan rumah dan menelan ribuan korban jiwa sehingga kondisi bencana menyebabkan masyarakat yang berada di sekitar wilayah bencana harus mengungsi untuk mencari tempat yang lebih aman dan perpindahan tersebut menjadikan masyarakat akan tinggal di tempat yang memiliki segala keterbatasan, baik dari segi sandang, pangan maupun papan $(2,3)$.

Terjadinya bencana berdampak pada ketersediaan pangan yang terbatas akan sangat berdampak kepada kondisi pertumbuhan dan perkembangan remaja yang merupakan masa perubahan atau peralihan dari masa kanak-kanak ke masa dewasa yang meliputi perubahan biologik, perubahan psikologik, dan perubahan sosial $(4,5)$. Masa remaja merupakan masa emas dimana anak harus dibekali makanan yang cukup gizi sebagai fondasi atau acuan dasar untuk kelangsungan hidupnya yang akan datang tanpa mengalami gangguan yang akan mengganggu proses tumbuh kembang anak karena usia tersebut adalah termasuk rentan gizi 
yang harus mendapat perhatian penting (6). Asupan gizi remaja akan menentukan jumlah zatzat gizi yang diperlukan oleh remaja untuk pertumbuhan dan perkembangannya (7).

Asupan gizi yang kurang bisa mempengaruhi status gizi remaja sehingga akan menimbulkann masalah pertumbuhan dan perkembangan yang tidak optimal, dan juga dapat rentan terhadap penyakit degenerative berupa, kanker osteoporosis dan kardiovaskular di usia tua (8). Penelitian yang dilakukan Mokoginta (2016) pada remaja mengungkapkan Angka kecukupan gizi pada remaja termasuk sangat kurang yaitu kecukupan energi sangat kurang (97,5\%), kecukupan karbohidrat $<70 \%$ AKG $(95 \%)$, protein $<70 \%$ AKG $(77,5 \%)$, dan lemak $<70 \%$ AKG (77,5\%) (9). Hasil penelitian Nisa (2019) didapatkan bahwa sebagian besar pola makan remaja cukup sebanyak 45 responden (54,9\%), sebagian besar jenis makanan yang dikonsumsi remaja tidak lengkap sebanyak 56 responden $(68,3 \%)$, sebagian besar frekuensi makan remaja kurang sebanyak 47 responden (57,3\%), dan sebagian besar jumlah makanan remaja kurang sebanyak 67 responden $(81,7 \%)$ (10). Penelitian ini bertujuan untuk mengetahui ketahanan pangan, asupan zat gizi dan indeks masa tubuh (IMT) pada remaja pasca bencana di Kota Palu yang merupakan daerah terdampak bencana alam gempa bumi, tsunami, dan liquifaksi.

\section{METODE}

Penelitian ini adalah penelitian survey deskriptif. Teknik pengambilan sampel pada penelitian ini menggunakan simple random sampling dengan jumlah 135 responden pada sekolah yang dekat dengan lokasi bencana gempa bumi, tsunami dan liquifaksi di Kota Palu yaitu SMP Negeri 3 Palu. karena adanya masa pandemi yang membatasi pertemuan yang juga mempengaruhi penelitian ini maka sampel yang dapat diperoleh sebanyak 96 orang Pengambilan data dengan menggunakan kuesioner ketahanan pangan, Food Recall, serta pengukuran indeks masa tubuh (IMT) menggunakan Timbangan dan microtoise. Data berupa analisis univariat dengan teknik analisis deskriptif persentase menggunakan bantuan software SPSS. 
HASIL

Tabel 1

Distribusi Frekuensi Ketahanan Pangan Remaja

\begin{tabular}{ccc}
\hline Ketahanan Pangan & Frekuensi & Persentase (\%) \\
\hline Rawan pangan dengan kelaparan & 10 & 10,42 \\
Rawan pangan tanpa kelaparan & 27 & 28,12 \\
Tahan Pangan & 59 & 61,46 \\
Total & $\mathbf{9 6}$ & $\mathbf{1 0 0}$ \\
\hline
\end{tabular}

Sumber : Data Primer, 2020

Berdasarkan tabel tersebut, dapat diketahui bahwa remaja dengan kategori tahan pangan lebih besar $(61,46 \%)$ dibandingkan dengan kategori rawan pangan dengan kelaparan $(10,42 \%)$ dan kategori rawan pangan tanpa kelaparan $(28,12 \%)$.

Tabel 2

Distribusi Frekuensi Asupan Zat Gizi Remaja

\begin{tabular}{lcc}
\hline Asupan (Energi) & n & Persentase (\%) \\
\hline Kurang & 95 & 98,96 \\
Cukup & 1 & 1,04 \\
Lebih & 0 & 0 \\
Total & 96 & 100
\end{tabular}

Sumber : Data Primer, 2020

Berdasarkan tabel tersebut, dapat diketahui bahwa asupan energi dengan kategori kurang lebih besar $(98,96 \%)$ dibandingkan dengan kategori cukup $(1,04 \%)$ dan lebih $(0 \%)$.

\section{Tabel 3}

Distribusi Frekuensi Indeks Masa Tubuh (IMT) Remaja

\begin{tabular}{lcc}
\hline \multicolumn{1}{c}{ IMT } & n & Persentase (\%) \\
\hline Underweight & 56 & 58,33 \\
Normal & 29 & 30,21 \\
Overweight & 9 & 9,38 \\
Obesitas & 2 & 2,08 \\
Total & 96 & 100 \\
\hline Sumber: Data Primer 2020 &
\end{tabular}

Berdasarkan tabel tersebut, dapat diketahui bahwa indeks masa tubuh (IMT) siswa sebagian besar masuk dalam kategori underweight atau kurang (58,33\%). Sedangkan siswa dengan IMT normal hanya 30,21\% yang dapat dilihat bahkan tidak mencapai 50\%. Untuk 
IMT overweight atau berlebih sebanyak $9,38 \%$ dan yang mengalami obesitas sebanyak $2,08 \%$.

\section{PEMBAHASAN}

Hasil penelitian menunjukkan bahwa kategori remaja yang tahan pangan lebih besar dibandingkan dengan kategori remaja rawan pangan, baik dengan kelaparan maupun tanpa kelaparan. Berdasarkan wawancara dengan para responden, diketahui bahwa kondisi tahan pangan ini dikarenakan pemulihan situasi dan kondisi yang tergolong cepat. Masyarakat juga memperoleh bantuan pasca bencana, baik dari pemerintah maupun pihak luar atau swasta. Hasil penelitian ini sejalan dengan penelitian yang dilakukan di Aceh Jaya yang terkena banjir Fitri dkk (2017) menemukan bahwa kondisi tahan pangan yang terjadi pada daerah penelitian pasca bencana banjir

dikarenakan faktor fisik dalam hal ini adalah lahan pertanian pasca banjir tidak meninggalkan ekses yang negatif secara total namun masih ada hasil produksi padi pasca banjir yang dapat digunakan untuk memenuhi kebutuhan pangan masyarakat (11). Penelitian ini sejalan dengan penelitian Sutriningsih (2017) Lebih dari separuh responden (76\%) mempunyai ketahanan pangan keluarga kategori tinggi. Faktor yang mempengaruhi ketahanan pangan antara lain usia, pendapatan, dan jumlah anggota keluarga (12). Penelitian Roy (2017) mengungkapkan di antara responden, mayoritas 52,04 \% responden makan nasi setiap 4 hari pasca bencana dalam seminggu. 196 responden, 26,01\% konsumsi sayur setiap tiga hari, karena pada masa bencana dan pasca bencana sulit mendapatkan sayur. Karena tumbuhan dan lahan pertanian memiliki daya tahan yang rendah terhadap bencana. Tingkat konsumsi ikan responden pada masa pascabencana sangat rendah. Responden sebagian besar $(87,25 \%)$ tidak makan ikan selama hampir 30 hari dalam sebulan selama periode pascabencana (13).

Hasil penelitian menunjukkan bahwa $98,96 \%$ remaja pasca bencana mengalami kekurangan asupan energi. Berdasarkan wawancara dengan responden, diketahui bahwa siswa sudah aktif sekolah dan kesulitan memanajemen waktu makan. Hal ini dapat dilihat dari hasil kuesioner recall-24 jam, banyak siswa yang melewatkan waktu sarapan serta lebih banyak mengonsumsi makanan ringan dibandingkan dengan makanan utama. Penelitian yang dilakukan di Pengungsian Petobo Kota Palu juga sejalan dengan penelitian ini. Hasil yang diperoleh yaitu asupan energi kurang pada responden sebanyak $(93,2 \%)$ dengan rata-rata 
konsumsi sebanyak 1353,4 kkal dan belum mencukupi AKG disebabkan oleh frekuensi dan jumlah porsi makan responden yang sedikit serta lauk yang tidak bervariasi. Berdasarkan hasil recall yang dilakukan bahwa beberapa responden tidak melakukan sarapan sebelum berangkat ke sekolah sebesar 17 remaja $(28,8 \%)(14)$.

Hasil penelitian menunjukkan bahwa indeks masa tubuh (IMT) siswa sebagian besar masuk dalam kategori underweight atau kurang (58,33\%). Tingginya IMT kategori underweight ini dapat dikarenakan kurangnya asupan energi pada remaja pasca bencana sehingga dapat mempengaruhi berat badan yang merupakan salah satu indikator dari IMT. Sedangkan siswa dengan IMT normal hanya 30,21\%. Untuk IMT overweight atau berlebih sebanyak 9,38\% dan yang mengalami obesitas sebanyak 2,08\%.

Penelitian ini sejalan dengan Penelitian Husna (2020) 8,6\% memiliki status gizi sangat kurus, sebesar 17,6\% memiliki status gizi kurus, sebesar 5,9\% memiliki status gizi gemuk dan $5,1 \%$ memiliki status gizi obesitas. Status gizi seseorang dipengaruhi oleh faktor langsung dan faktor tidak langsung. Adapun faktor langsung dari status gizi seseorang dipengaruhi oleh asupan makanan dan penyakit infeksi (15). Sejalan juga dengan penelitian Nasrul (2019) Status gizi sesudah bencana menurut BB/U didapatkan 3 anak berstatus gizi buruk (5,7\%), 13 anak yang berstatus gizi kurang (24,5\%) dan 37 orang (69,8\%) yang berstatus gizi baik. Pasca bencana masalah gizi naik, dimana faktor terjadinya masalah gizi muncul di tempat pengungsian kurangnya bahan makanan yang terjamin nilai gizinya, lingkungan tempat tinggal yang kurang bersih pasca bencana yang dapat menimbulka penyakit, serta pola asuh dan kurangnya pendapatan orang tua yang mengakibatkan ekonomi kurang pasca bencana (16).

\section{KESIMPULAN DAN SARAN}

Status ketahanan pangan dengan kategori tahan pangan lebih besar dibandingkan dengan kategori rawan pangan tanpa kelaparan dan rawan pangan dengan kelaparan. Remaja dengan kategori asupan gizi kurang lebih besar dibandingkan dengan remaja dengan kategori asupan gizi cukup dan normal. IMT siswa dengan kategori underweight atau kurang lebih besar $(58,33 \%)$ dibandingkan dengan tiga kategori lainnya 


\section{DAFTAR PUSTAKA}

1. Tanjung R, Mulyadi D, Arifudin O, Rusmana FD. Manajemen Mitigasi Bencana [Internet]. Widina Bhakti Persada Bandung; 2020 [cited 2021 Jun 16]. Available from: https://repository.penerbitwidina.com/publications/323887/

2. Pradipta SRR. Laporan Kegiatan Relawan Tim Medis Bencana Alam Palu Sulawesi Tengah 08-23 Oktober 2018. 2018;

3. Pusat Data Informasi dan Humas. Gempabumi Dan Tsunami Sulawesi Tengah. Jakarta: BNPB; 2019.

4. Ryska H, Hadju V, Sirajuddin S. Gambaran Pengetahuan, Sikap, Ketersediaan Buah Dan Sayur Ditingkat Rumah Tangga Dan Pola Konsumsi Buah Dan Sayur Pada Remaja Sma Di Kabupaten Gowa. Ilmu Gizi Fakultas Kesehatan Masyarakat Universitas Hasanuddin. 2014;1(2):1-9.

5. Azmiyati U. Bencana dan Ketahanan Pangan Adaptasi Masyarakat Gumantar Ketika Terjadi Bencana. JISIP (Jurnal Ilmu Sosial dan Pendidikan) [Internet]. 2019 Mar 3 [cited 2021 Jun 16];3(1). Available from:

6. http://ejournal.mandalanursa.org/index.php/JISIP/article/view/610

7. Panjaitan WES. Hubungan Persepsi Body Image, Perilaku Makan Dan Status Gizi Pada Remaja. 2013 Nov 9 [cited 2021 Jun 16];0(0). Available from: https://digilib.esaunggul.ac.id/UEU-Undergraduate-200632008/755

8. Rachmayani SA, Kuswari M, Melani V. Hubungan Asupan Zat Gizi dan Status Gizi Remaja Putri di SMK Ciawi Bogor. Indonesian Journal of Human Nutrition. 2018 Dec 31;5(2):125-30.

9. Tomasoa VA, Dary D, Dese DC. Hubungan Asupan Makan dan Aktifitas Fisik Terhadap Status Gizi Anak Usia Sekolah. Jurnal Keperawatan Muhammadiyah

10. [Internet]. 2021 Jun 2 [cited 2021 Jun 16];6(2). Available from: http://journal.umsurabaya.ac.id/index.php/JKM/article/view/7819

11. Mokoginta FS, Budiarso F, Manampiring AE. Gambaran Pola Asupan Makanan Pada Remaja di Kabupaten Bolaang Mongondow Utara. Jurnal E-Biomedik. 2016;4(2).

12. Nisa N. Gambaran Pola Makan Pada Remaja Kelas VII Dan VIII Di SMPN 1 Pringapus Kecamatan Pringapus Kabupaten Semarang [Internet] [s1]. Universitas Ngudi Waluyo; 2019 [cited 2021 Jun 16]. Available from: http://repository2.unw.ac.id/55/

13. Fitri R, Agussabti, Safrida. Analisis Ketahanan Pangan (Tanaman Padi) Pada Wilayah Yang Terkena Banjir Di Kecamatan Krueng Sabee Kabupaten Aceh Jaya. Jurnal Ilmu Kebencanaan : Program Pascasarjana Unsyiah [Internet]. 2017 [cited 2021 Jun 16];4(4). Available from: http://202.4.186.66/JIKA/article/view/13348

14. Sutriningsih A, Lasri L. Ketahanan Pangan Keluarga Berkaitan dengan Status Gizi Balita Pasca Erupsi Gunung Bromo di Kabupaten Malang. Care: Jurnal Ilmiah Ilmu Kesehatan. 2017 Jul 31;5(2):263-76.

15. Roy T, Dutta S. Post-Disaster Food Habit And Dietary Pattern Of Women Of Khulna District In Bangladesh. Khulna University Studies. 2017;14(1):243-55.

16. Widnatusifah E, Battung S, Bahar B, Jafar N, Amalia M. Gambaran Asupan Zat Gizi Dan Status Gizi Remaja Pengungsian Petobo Kota Palu. JGMI [Internet]. 2020 May 29 [cited 2021 Jun 16];9(1). Available from: 
https://journal.unhas.ac.id/index.php/mgmi/article/view/10155

17. Husna A, Sulastri, Marthoenis. Depression and Nutritional Status of Teenagers Following 2016 Aceh Earthquake. In: Challenges in Nursing Education and Research. CRC Press; 2020.

18. Nasrul N, Candriasih P, N.a A. Status Gizi Anak Balita Pasca Bencana Di Pengungsian Kelurahan Buluri Kota Palu Provinsi Sulawesi Tengah. Jurnal GIZIDO. 2019 Nov $1 ; 11(2): 71-80$. 